"What do we know about empirical joint audit research? A literature review"

\begin{tabular}{|c|c|}
\hline AUTHORS & $\begin{array}{l}\text { Patrick Velte (D https://orcid.org/0000-0001-5960-8449 } \\
\text { R http://www.researcherid.com/rid/H-1488-2017 }\end{array}$ \\
\hline ARTICLE INFO & $\begin{array}{l}\text { Patrick Velte (2017). What do we know about empirical joint audit research? A } \\
\text { literature review. Accounting and Financial Control, 1(1), 4-14. } \\
\text { doi:10.21511/afc.01(1).2017.01 }\end{array}$ \\
\hline DOI & http://dx.doi.org/10.21511/afc.01(1).2017.01 \\
\hline RELEASED ON & Wednesday, 19 April 2017 \\
\hline RECEIVED ON & Saturday, 11 March 2017 \\
\hline ACCEPTED ON & Tuesday, 11 April 2017 \\
\hline LICENSE & $\begin{array}{l}(c) \text { EY-NG } \\
\text { This work is licensed under a Creative Commons Attribution-NonCommercial } 4.0 \\
\text { International License }\end{array}$ \\
\hline JOURNAL & "Accounting and Financial Control" \\
\hline ISSN PRINT & $2543-5485$ \\
\hline ISSN ONLINE & $2544-1450$ \\
\hline PUBLISHER & Sp. z o.o. Kozmenko Science Publishing \\
\hline FOUNDER & Sp. z o.o. Kozmenko Science Publishing \\
\hline
\end{tabular}

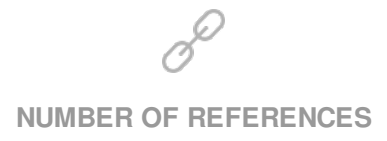

20

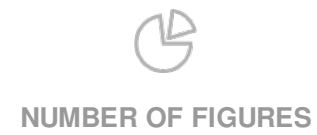

1
NUMBER OF TABLES

2

(C) The author(s) 2023. This publication is an open access article. 
Patrick Velte (Germany)

\title{
What do we know about empirical joint audit research? A literature review
}

\begin{abstract}
This literature review evaluates empirical studies which concentrate on economic effects on joint audits from an international perspective. We briefly introduce the theoretical and empirical joint audit framework that comprises an adequate structure of the state-of-the-art of empirical research in this field. This is followed by a discussion of the following output factors of joint audits: (1) audit quality; (2) audit costs and (3) audit market concentration. We will summarize the key findings in each area, and provide a description of the analyzed proxies. Finally, we will discuss the current limitations of the studies and give useful recommendations for future empirical research activities in this topic.
\end{abstract}

Keywords: audit quality, earnings quality, audit market concentration, auditor independence, empirical audit research, audit fees, joint audits, audit costs, accruals, earnings management.

JEL Classification: M40, M42.

Received on: $11^{\text {th }}$ of March, 2017.

Accepted on: $10^{\text {th }}$ of April, 2017.

\section{Introduction}

A comprehensive debate provoked by the financial crisis of 2008/09 and the general observation that more accurate tools are required to assure the veracity of companies' financial statements to stakeholders has resulted in extensive empirical research on joint audits in terms of audit quality, audit costs and market concentration from an international perspective (Quick, 2012; Bédard et al., 2016). Mandatory joint audits, as legally required in France since 1966 and proposed in the European Commission's (EC) green paper of 2010 (EC, 2010) were to be conducted by a Big Four firm and a second-tier auditing company jointly, a move justified by the oligopoly on the European market and with the intention to reduce the market concentration of just a few companies and to introduce the quality of audits (EC, 2010). EU legislation to statutory auditing as adopted in the reform of April 2014 still does not make joint audits a mandatory requirement in Europe (EC, 2014) but voices have become louder in recent years on the economic need of joint audits and a large amount of empirical research has produced many interesting new aspects on the topic (Ratzinger-Sakel et al., 2013). Based on the insights resulting from such research, joint audits appear to have a significant impact on 1) the audit quality 2) audit costs, and 3)

\footnotetext{
(c) Patrick Velte, 2017.

Patrick Velte, Ph.D., Professor of Accounting and Auditing, Institute of Banking, Finance and Accounting, Leuphana University of Lueneburg, Germany.

This is an Open Access article, distributed under the terms of the Creative Commons Attribution-NonCommercial 4.0 International license, which permits re-use, distribution, and reproduction, provided the materials aren't used for commercial purposes and the original work is properly cited.
}

audit market concentration. Since their publication, the audit reform proposals have stimulated much research in this field mainly in Europe (Quick, 2012) but the effects of joint audits have also led to studies in other judicial areas with mandatory and voluntary joint audits worldwide (e.g. Kuwait, Egypt; Alfraih, 2016; El Assy, 2015).

Economically relevant aspects of mandatory joint audits are restricted (self-organization in the audit profession and less corporate flexibility). The quality of external auditing should prevent the kind of accounting scandals we have seen in the past and reduce fraud on management levels while contributing positively towards efficient corporate governance, (e.g. internal audits, audit committees), together leading to greater capital market efficiency.

The objective of this paper is to analyze and evaluate the existing empirical studies on joint audits. The methodology and evaluation used is in line with vote counting of previously established significances (Light and Smith, 1971). This literature review synthesizes a number of major new insights and presents them for fruitful discussion that will lead to new research paths. The following review should provide useful data for researchers, regulators and practitioners alike. The economic effects of joint audits can be investigated further in future and practitioners will gain insights in the progress of joint audit composition and resources. The findings will also stimulate the development of joint audit standards from a regulatory perspective.

This article is structured as follows: After introducing the theoretical and empirical joint audit framework (Section 1) the findings from empirical studies are being appraised (Section 2), followed by a presentation of the methodology (Section 
2.1) and a discussion of the impact on audit quality (Section 2.2), audit costs (Section 2.3) and audit market concentration (Section 2.4). Lastly the restrictions of existing empirical research receive consideration and recommendations are presented for future research activities (Section 3).

\section{Joint audit framework}

1.1. Theoretical framework. 1.1.1. Audit quality. In our analysis, special attention is paid to the classical principal-agent theory (Ross, 1973; Jensen and Meckling, 1976), though external auditing can be classified as a monitoring and bonding instrument for management activities to safeguard an adequate quality of financial reporting (Chow, 1982). Since investors rarely have sufficient time for intensive analysis of financial data or professional resources and as there is rational apathy in Public Interest Entities (PIEs) with an increased degree of freefloat, third-party professionals are commissioned to carry out external audits of financial reports. The relationship between external auditor and the capital market is reflected in the gatekeeper function. Antle (1982) defines the auditor as an economic agent and attributed to the classic agency conflicts of hidden characteristics, information, action and transfers, resulting in the risks of adverse selection and moral hazard. The principal-agent issues of an auditor may impair his ability and freedom to make a sound assessment. Adverse selection may be the result of an auditor's lack of qualifications, or his bias towards the audited company. Beyond this principal-agent conflict that may arise in the pre-contractual period, information asymmetries pose the danger of a moral hazard and improper audits (shirking) and assessments. Other moral hazards in the form of collaboration between management and auditors can also arise, where auditors may tolerate poor quality financial reporting and, based on these, produce unqualified audit opinions in exchange for hidden transfer benefits.

Joint audits can enhance audit quality due to the prevention of auditor dependence. A long-term single contract between client and auditor seems sensible, the independence in appearance might be limited due to a special trust relationship between management and auditor in a long-term assignment. Literature assumes stricter and more relentless audits under joint audits, because the auditor intents to diminish the risk of having his successor complain about his low performing upon review of years' audits. The avoidance of organizational blindness under joint audits is pointed out, as negatively influencing the audit efficiency, even under observation of independence. Hence, the long-term single auditor simply trusts his results from previous years instead of anticipating important changes in the company development and adjusting his auditing strategy.

1.1.2. Audit costs. Traditional agency models neglect auditor changes, with extreme cases allowing for indefinite mandates. The risks of an asymmetrical distribution of information in audits can be magnified through the low balling phenomenon. Low balling indicates that the audit fees for the initial mandate as negotiated with the client do not cover the actual costs. This strategy can have a negative impact on auditor independence and lead to higher incentives to form a coalition with the management (DeAngelo, 1981a). According to the basic model of DeAngelo (1981a), the first audit will cause startup costs because the auditor will have to familiarize himself with the business activities and environment of the company first. The auditor chooses a low-balling strategy to crowd competitors out. These losses of the first audit represent a market entry barrier for competing auditor firms. These information and cost advantages are an additional market entry barrier in later audit cycles. Fee cutting, which implies a continuous increase of auditor fees through strategic market considerations, has a positive effect on quasi rents and strengthens the incentives for low-balling. A lack of fee cutting, however, does not necessarily mean that a low balling strategy was not utilized. Reversely, the presence of fee cutting is not necessarily evidence of a low balling strategy.

Although empirical evidence of the low balling strategy is difficult because the cost structures of an audit firm are not public, investigations at the Big Four audit firms have assumed a sort of order behavior alternatively on the basis of fee cutting in order to build a market entry barrier for small and medium audit firms (e.g. Schatzberg, 1990). In a joint audit it can be assumed that the incentives for low balling behavior are reduced. Generally, additional technical and time resources are necessary because of the "four-eyes" principle which has an increasing effect on audit costs. However, the precise configuration of the audit costs depends largely on the composition of the joint audit team (one or two Big Four auditors). If there is a "de facto joint audit" with equal partners, which implies an efficient division of audit procedures, cost reduction potential may also possibly be used.

1.1.3. Audit market concentration. European PIEs are predominantly audited by just a few big audit firms while small and medium size audit companies 
hardly ever get commissioned. The impact of audit market concentration on an international level has been analyzed in a number of studies (Velte and Stiglbauer, 2012). Over the past 25 years the audit market has undergone a development towards strong concentration. The competitive situation in the audit market and the tendencies towards supplier concentration can be discussed through numerous approaches used in industrial economics. Here, explanations are sought for on how the number of market players and their competitive interaction along with market imperfections, generated by offering heterogeneous products and services, and market entry barriers or asymmetric information influences the market behavior and the market structure.

De Angelo (1981b) was the first to argue that audit companies' reputation was often based on their size or more specifically on the number of clients they serve rather than the quality of their audits and it was assumed that they had therefore better industry specific resources than small and medium sized audit companies. According to deAngelo (1981b) the large companies would also have more to lose if the ignored any balance sheet manipulations and thereby caused damage to their reputation.

DeAngelo (1981b) has first applied the size of an audit company as a surrogate for audit quality. According to that, big audit firms - measured by the number of clients - tend to have more reputation and industry specific resources than small and medium sized audit companies. DeAngelo (1981b) explains this assessment with risk management processes because big audit firms are in the position to conduct many parallel PIE audits. The perceived independence of the market is higher in comparison to smaller audit firms with lower personnel and knowledge resources. Because of this great reputation challenge, according to DeAngelo (1981b) the probability increases that the auditor reports correctly accounting errors as well as balance sheet manipulations. As a follow-up study, Palmrose (1986) investigated the connection between audit firm size and audit fee. Hereby, it is assumed, that big audit firms demand a markup when owning a market position approaching such as that of a monopoly, in order to signalize higher audit quality. These hypotheses are contrary to low balling, after which audit firms agree with the client upon a not cost-covering audit fee in the first audit period hoping this would lead to future rationalization effects. Consequently, it is examined whether the existence of economies of scale entails lower audit fees of audit companies in comparison to competition.

A joint audit between a big four audit firm and a smaller audit firm is connected with a decreased audit market concentration. But these advantages cannot be realized by joint audits, since there are two Big Four audit companies involved and not a joint determination between a Big Four and non-Big four audit firm. Furthermore, practical experience suggests frequent changes from small to larger audit companies. Insofar, auditor choice within joint audit regimes seems to be a crucial factor. Insofar, also mandatory audit firm rotation that was introduced by the European audit regulation 2014 for PIEs, would not lead to lower audit market concentration since the rotation will be conducted within the Big Four.

1.2. Research framework. In the context of this literature review the creation of a joint audit research framework is used to outline the main strengths of research (Figure 1). Here the link between carrying out a mandatory or a voluntary joint audit and specific outcome measures are stressed for the main points of this review. We look first at the assessment of audit quality impact while so far earnings quality variables were chiefly considered. In a next step the impact of joint audits on audit costs are examined. Audit fees which are reported in the notes or transparency reports will be used as basis since the cost structures of audit firms are not publicly accessible. Last but not least, few studies regard the link between joint audits and audit market concentration by various concentration measures.

An explicit joint audit framework does not exist up to now. We rely on the research structure by Ratzinger-Sakel et al. (2013) with a special modification. Ratzinger-Sakel et al. (2013) explain the impact of joint audits on audit quality, audit costs and audit market concentration and add "other studies on joint audits" (such as determinants for opting for joint audits where a joint audit is chosen voluntarily; determinants for the pair choice of auditors and the possible impact of auditor pair choice on how audit fees are divided between the joint auditors and also the effect on audit quality based on pair choice). We integrate the strand of research with a focus on auditor choice in the respective analysis of audit quality and audit cost. 


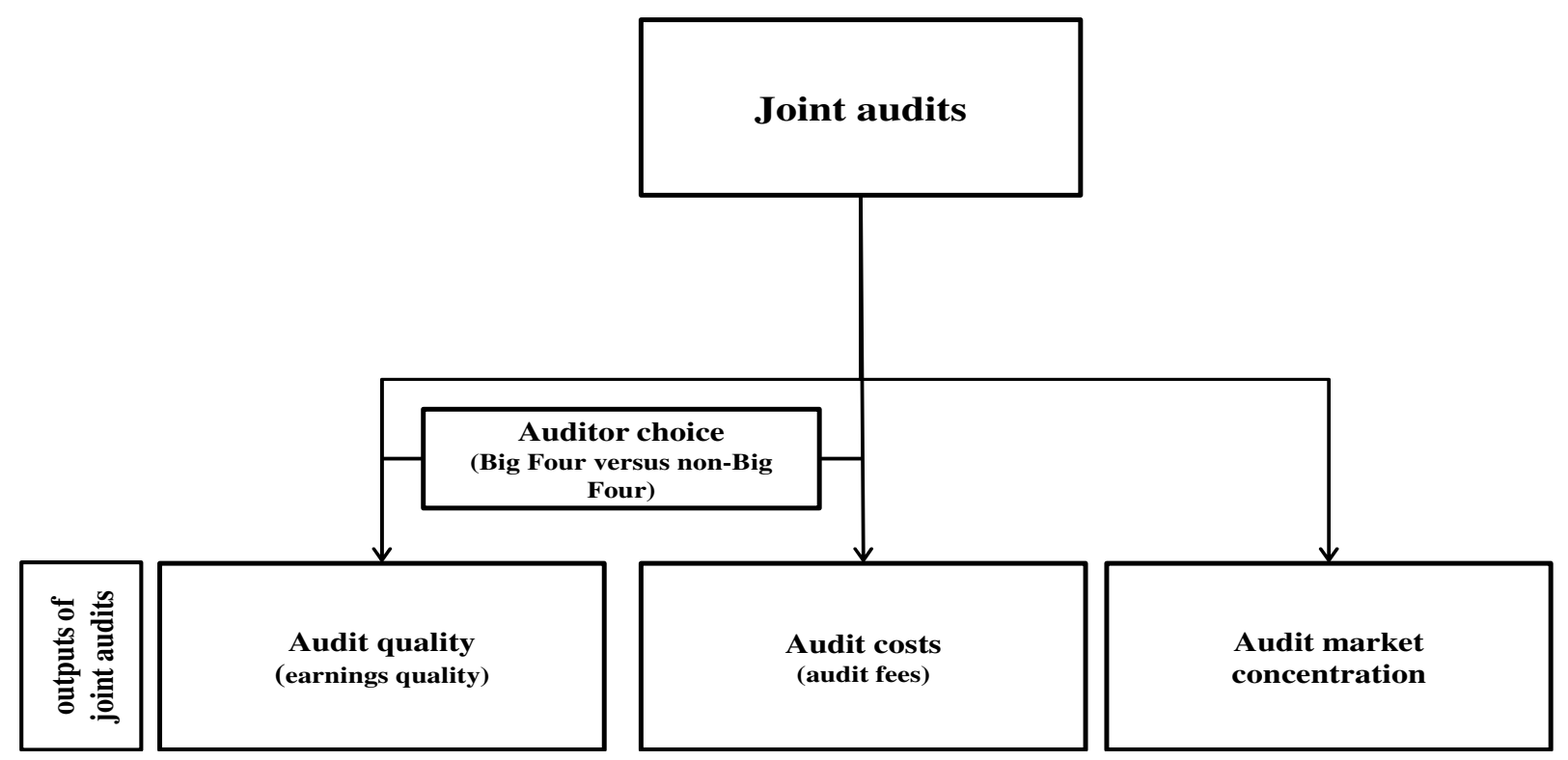

Fig. 1. Joint audit research framework

\section{Review of joint audit research}

2.1. Data. International data resources (web of science, google scholar, SSRN, EBSCO, science direct) and library resources for the empirical studies were included in this literature review. The keywords used in the targeted search were "joint audit(s)" in combination with "audit(s)", "financial reporting", "external audit(s)", "audit market concentration", "audit concentration", "auditor choice", "earnings quality" or technically associated terms (e.g. "financial accounting" or "financial reporting quality"). Certain broader terms were also used to expand on the topic such as "corporate governance" or, to narrow the search, such specific variables as "Big Four". The search findings were later reviewed in terms of their suitability for the study and contrary to earlier research on joint audit regimes the study was not limited to a specific country.

Due to the limited number of studies available it was not practical to restrict our studies to a certain period of time. In addition to archival studies that provided most of our research material some interviews have also been included where economic correlations between selected outputs of joint audits through multivariate analysis and analytical models were measured. To safeguard the quality of the studies only those that have been published in international journals with double blind reviews were included (final sample: 21 ).

The following overview of current research in the area of joint audits allows a systematic mapping and analysis of the current international state of research for this joint audit framework, for the first time. A quantitative literature analysis in the form of vote counting (Light and Smith, 1971) focuses the significant findings and their respective signs, but ignores the specific coefficient values. The underlying primary studies are assigned the expressions significant positive (+) and significant negative (-).

This literature review contributes to the present controversial discussion because it synthesizes a number of major new insights from the literature and offers a basis for rich discussion on future research avenues. In contrast to former reviews on that topic, we have a clear structure for joint audit research, including influencing factors to joint audits and the main results of empirical research via vote counting are presented. The analysis provides crucial added value compared to previous surveys of empirical research (Bédard et al., 2016; RatzingerSakel et al., 2013; Quick 2012). Bédard et al. (2016) only reflect the empirical joint audit research in France. Quick (2012) also analyzes other EC reform measures (e.g. audit form rotation, restriction of non-audit services) without a special research framework on joint audits. Ratzinger-Sakel (2013) use a similar research structure but also mention "other studies on joint audits". We include these aspects in the three main research strands. It has to be noted that due to the small number of studies, no meta-analysis exists so far. As we expect new results from a broad range of output factors attributes together with a vote counting approach for this review, we will also stress the research limitations and give future research recommendations.

Table 1 provides an overview of the number of contributions included in each research strand, the 
year of publication, the states examined, and the journals in which the contributions were published. Half of the evaluated contributions focus on the impact of joint audits on audit quality (11) and audit costs (12). Only two studies dwell on the effects of audit market concentration. The analyses were published or prepared in the years 2007 to 2016. As explained above, European samples dominate all research strands. Only two studies focus on NonEU-countries (Kuwait; Egypt). Many of the research findings were published in leading accounting journals, e.g. European Accounting Review.

Table 1. Count of published papers cited

\begin{tabular}{|c|c|c|c|}
\hline & Audit quality & Audit costs & Audit market concentration \\
\hline \multicolumn{4}{|c|}{ Panel A: by publication year } \\
\hline & $\begin{array}{l}2009: 1 \\
\text { 2012: } 2 \\
\text { 2015: } 4 \\
2016: 4\end{array}$ & $\begin{array}{l}2007: 1 \\
2008: 1 \\
2010: 1 \\
2012: 2 \\
2014: 2 \\
2015: 2 \\
2016: 3\end{array}$ & $\begin{array}{l}\text { 2007: } 1 \\
2008: 1\end{array}$ \\
\hline Total: 25 & 11 & 12 & 2 \\
\hline \multicolumn{4}{|c|}{ Panel B: by state } \\
\hline & $\begin{array}{c}\text { Kuwait: } 1 \\
\text { Egypt: } 1 \\
\text { France: } 4 \\
\text { Italy: } 2 \\
\text { UK: } 1 \\
\text { Denmark: } 1 \\
\text { Finland: } 1 \\
\text { Sweden: } 2 \\
\text { Germany: } 2 \\
\text { Austria: } 1 \\
\end{array}$ & $\begin{array}{c}\text { France: } 4 \\
\text { Italy: } 1 \\
\text { UK: } 1 \\
\text { Denmark: } 5 \\
\text { Finland: } 2 \\
\text { Sweden: } 4\end{array}$ & $\begin{array}{c}\text { France: } 1 \\
15 \text { EU countries: } 1\end{array}$ \\
\hline Total: 35 & 16 & 17 & 2 \\
\hline \multicolumn{4}{|c|}{ Panel C: by journal } \\
\hline & $\begin{array}{c}\text { Journal of Financial Regulation and } \\
\text { Compliance: } 1 \\
\text { European Accounting Review: } 3 \\
\text { International Journal of Business } \\
\text { Research and Development: } 1 \\
\text { Auditing: } 3 \\
\text { International Journal of Accounting } \\
\text { and Financial Reporting: } 1 \\
\text { British Journal of Applied Science \& } \\
\text { Technology: } 1 \\
\text { International Journal of Economic } \\
\text { Sciences \& Applied Research: } 1\end{array}$ & $\begin{array}{c}\text { European Accounting Review: } 3 \\
\text { International Journal of Auditing: } 3 \\
\text { Euroepan Accounting Review: } 1 \\
\text { Auditing: } 1 \\
\text { Managerial Auditing Journal: } 2 \\
\text { Corporate ownership \& control: } 1 \\
\text { Contemporary Accounting Research: } 1\end{array}$ & $\begin{array}{c}\text { International Advances in Economic } \\
\text { Research: } 1 \\
\text { Managerial Auditing Journal: } 1\end{array}$ \\
\hline Total: 25 & 11 & 12 & 2 \\
\hline
\end{tabular}

2.2. Audit quality. A main focus of empirical joint audit research is the impact on audit quality. As it is not possible to measure audit quality directly, a number of proxies are commonly used in empirical research (Knechel et al., 2013; DeFond and Zhang, 2014). Current research has focused on earnings quality measures as a proxy for audit quality. According to agency theory, opportunistic accounting policy promotes asymmetric information between management and shareholder, because exercising options and utilizing discretionary powers in financial reporting conflicts with decision usefulness. By their monitoring effects, two joint auditors should provide management incentives for less earnings manipulations and improved management behavior. Consequently, earnings quality becomes a better key decision-making tool for investor decisions.
From an international perspective, the estimation of earnings quality frequently focuses on accruals models (Dechow et al., 2010). Abnormal accruals are the difference between the annual result (based on the income statement) and the operational cash flow, i.e. it shows results of the financial year not affecting cash (e.g. changes in provisions, depreciation of assets). The accruals models assume that the existence of accruals has no negative impact on quality if their amounts are not excessive. Only if they can be classed as abnormal or discretionary, opportunistic management behavior as an accounting policy will be associated with reduced earnings quality (Dechow et al., 2010). Accruals models showing an accounting policy in the accounts after the balance sheet date are highly popular in empirical research, as both their calculation and the procurement of the data is easy. 
The first popular accruals model (see also Gros and Worret, 2014) was developed by Jones (1991). Various modifications exist (modified Jones-model by Dechow et al., 1995; forward-looking Jonesmodel by Dechow et al., 2003; ROA-model by Kothari et al., 2005; Dechow and Dichev, 2002).

Previous empirical studies have mostly shown a positive impact of joint audits on the audit quality in different countries (Kuwait, Italy, France, Egypt, Finland, Sweden, Austria). In this context, in part, the effect of a specific joint audit composition is considered (Big Four versus non Big Four). The comparability is however limited because both mandatory and voluntary joint audit regimes are considered. Alfraih (2016) analyzes the audit delay as proxy for audit quality in Kuwait for the 2013 financial year and finds a positive relationship with one or two Big Four auditors in the joint audit. Bisogno and De Luca (2016) also established a quality-enhancing effect of joint audits in Italy for the 2010 financial year. The authors used an alternate proxy of earnings management (occurrence of small positive earnings). For the French audit market, which is the only EU Member State that provides a mandatory joint audit regime, the audit quality increased according to Bennouri et al. (2015) from the period 2002-2008 due to joint audits if two Big Four auditors form the joint audit team. The audit quality was approximated on the basis of reports on related-party transactions. According to Francis et al. (2009), who examined the 2003 financial year in France, one or two Big Four joint auditors are associated with lower abnormal accruals. Companies with fewer concentrated ownership structures and lower rates of family ownership appoint at least one Big Four joint auditor. According to El Assy (2015), joint audits also go hand in hand with higher earnings conservatism in Egypt for the years 2009-2013. The author stresses that there is no difference between voluntary and mandatory joint audits and no difference in auditor choice (Big Four versus non Big Four). Based on abnormal accruals, joint audits in Finland and Sweden for the period 2005-2009 are also connected with improved audit quality according to Ittonen and Trønnes (2015) According to Zerni et al. (2012), joint audits in Sweden during the period 2001-2007 led to higher earnings conservatism, lower abnormal accruals, better credit ratings, and better risk forecasts. Baldauf and Steckel (2012) surveyed 35 statutory auditors in Austria and Germany and confirmed a higher degree of auditor consensus in the auditor's report with joint audits.

Unlike the previous empirical findings, there are also studies that find joint audits have no effect on the audit quality. This is true for the study by Andre et al. (2016) who studied the change in abnormal accruals in a transnational sample (France, Italy, UK) for the period 2007-2011. The same applies to the study by Lesage et al. (2016) for Denmark in the period 2002-2010. In a country comparison between Germany (voluntary joint audit) and France (mandatory joint audit) for the financial years 20082012, Velte and Azibi (2015) also found no evidence of an effect on abnormal accruals.

2.3. Audit costs. The discussion of joint audits is often closely linked to its effect on audit costs. As the cost structure of audit firms is usually not made public, researchers have come to use audit fees as the best available substitute. These fees can be found both in the notes to the reports that PIEs have to publish and in the transparency reports from the audit firms. Audit as well as non-audit fees, incidentally, are also important yardsticks of audit quality in empirical single audit research, though not in joint audit research. They should indicate audit efficiency and not audit quality (auditor independence) in this environment because dependency risks in a joint audit are lower in comparison to a single audit.

The previous findings on the influence of joint audits on audit fees tend to indicate a positive connection. The transnational study by Andre et al. (2016) for France, Italy, and the UK found higher audit fees in a joint audit compared to the single audit. Lesage et al. (2016) (for the period 2002-2010) and Holm/Thinggaard (2016) (for the period 2005-2007) also measured a positive effect in Denmark. The connection is established by Holm and Thinggaard (2016) if there is a big-small joint audit and when the small joint auditor has a share of less than $25 \%$. According to Nekhili et al. (2014), there are higher audit fees in France for the financial years 2004-2006 for both one and two Big Four joint auditors. Likewise, for the French audit market (financial year 2002), a joint audit with a non-Big Four audit firm is associated with higher audit fees by GonthierBesacier and Schatt (2007). A positive correlation was also found in Sweden for the financial years 2001-2007 by Zerni et al. (2012). In Denmark, which has not provided mandatory joint audits from the 2005 financial year, the audit fees were reduced after the change to a single audit if a dominant auditor was commissioned (Holm and Thinggaard, 2014). In contrast, de facto joint audits with equivalent partnerships are associated with lower audit fees by Thinggaard and Kiertzner (2008) in Denmark in 2002. Analogous to this, Gonthier-Besacier and Schatt (2007) found declining audit fees in France in 2002 with two Big Four auditors. 
Analogous to the audit quality, empirical studies can be found that have measured no influence of joint audits on audit fees. This confirms AudoussetCoulier (2015) in France in 2002-2003 in a joint audit with two Big Four auditors, whereby there are signs of a Big Four price premium. There was also no evidence in Finland and Sweden for the period 2005-2009 by Ittonen and Trønnes (2015). The same applies to the study by Ittonen and Peni (2012) for Denmark, Finland, and Sweden for 2005-2006 and by Zerni et al. (2010) for Sweden over the period 2000-2006.

2.4. Audit market concentration. The measure of audit market concentration in previous empirical studies is characterized by heterogeneity. Using absolute (relative) concentration variables, the number (share) of certain audit companies on the whole market volume is considered. The concentration rate (CR) and the HerfindahlHirschmann Index (HHI) are to be distinguished as absolute measures, while the Gini-coefficient (G) and the Lorenz curve are mentioned as relative measures.

Unlike the first two research strands, so far there are only two studies which measure the impact of joint audits on the audit market concentration. In this respect, there is an essential need for future research. Ballas and Fafaliou (2008) studied 15 European countries in the period 1998-2004 with a broad sample. After this, lower concentration rates were seen in France and Denmark as mandatory joint audit regimes after the collapse of Arthur Andersen, while in the other EU countries the audit market concentration increased. In the study by Piot (2007), focusing the French audit market for 1997 and 2003, the audit market concentration in France was also lower compared to other EU member states. However, the concentration has increased in France over time. It remains unclear, however, how the concentration changes are explicitly attributed to the existence of joint audits.

Table 2 in Appendix summarizes the results of the empirical joint audit studies.

\section{Limitations of former empirical research and recommendations for future research}

Most empirical research on joint audits has so far been carried out in Europe. As far as the US American market is concerned very little research has been done leaving a major research gap. The differentiation between one and two tier systems has also been ignored so far as have been other corporate governance variables such as the composition of boards and audit committees. Also other corporate governance variables, e.g. board or audit committee composition, are not included in detail. As the main intention of the European audit regulation in 2014 was to strengthen the relationship between audit committee and external auditor, an active and independent audit committee might have more incentives to establish a joint audit in comparison to a single audit. Insofar, further research activities should include these audit committee and other board interactions to get a deeper insight in voluntary joint audit regimes. Furthermore, also in mandatory joint audit regimes, the determinants of joint partner selection (Big Four versus Non Big Four) will be mainly influenced by the internal corporate governance structure within the company.

Irrespective of these variations, there are methodological limitations that existing empirical studies are subject to such as the fact that neither audit quality, nor the audit costs can be determined directly and therefore need to be estimated (Dechow et al., 2010). The significance of these substitute measures is limited. This is particularly true with the widely used abnormal accruals models which are always associated with negative earnings quality as a marker for earnings management (Gros and Worret, 2014). In particular, the differentiation between normal and abnormal accruals is characterized by a lack of comparability which is reflected in the diversity of empirical research models. This limited impact of estimate variables also affects the assessment of audit costs (e.g. based on audit fees) (DeFond and Zhang, 2014). Only few empirical studies have examined the impact of joint audits on audit market concentration, and even here, many interdependencies will contribute to the concentration level, not only the decision to conduct a joint audit (voluntary regime) or the joint audit pair choice (mandatory regime). However, it must be considered that the majority of the studies now conduct sensitivity analyses and robustness checks, and increasingly take endogeneity problems into account, e.g. by using instrumental variables (Larcker and Rusticus, 2010).

Hereafter, recommendations for future research activities shall be given. The literature review of empirical research activities on joint audits shows that the principal-agent theory and the shareholder value approach are still dominant. However, research increasingly takes an interest in the extent to which external audits also influence other stakeholders' decision-making behavior and nonfinancial aspects (on a current literature review on CSR research in accounting in this journal, see Huang and Watson, 2015). According to the 
legitimacy theory (Shocker and Sethi, 1973), an organization must continuously legitimize itself to society through appropriate CSR management to maintain its status as a "good corporate citizen" (Wood, 1991). In order to drive stakeholder value through CSR activities, the decision to conduct a joint audit can be crucial for a successful CSR management quality. This issue has not been included in empirical joint audit research.

With respect to dominant considerations of joint audits on audit quality, audit costs and audit market concentration, the attempts to achieve more precise variable measurements must be appreciated. In this context, we must get a closer look on the decision process both in the audited and auditing firms by qualitative research designs (e.g. interviews, case studies). Also the stakeholder perceptions of joint audits in comparison to single audits should be analyzed in greater detail with the help of qualitative research.

Finally, the impact of joint audits on audit quality, audit costs and audit market concentration has only been at the focus of few studies across several countries on a larger scale so far (e.g. Ballas and Fafaliou, 2008). This should therefore be the starting point for more research in the future so that the effects of voluntary and mandatory joint audit regimes would become apparent on a country-level.

\section{Conclusion}

Since the green paper was presented by the EC in 2010 after the financial crisis of 2008/09 joint audits have received much attention from the research community. Though European legislators have introduced major changes to external auditing of PIEs, such as external rotation and restriction of non-audit duties, joint audits are still only mandatory in France while in the rest of Europe they are still voluntary. The actual economic benefit of joint audits has been the topic of much controversial debate ever since the European audit reform. Great attention is also being paid, in this context, on the impact of joint audits on audit quality, audit fees and audit market concentration.

This structured literature review evaluates the empirical research to this topic. After deriving a theoretical and empirical joint audit framework, the structure was further organized into audit quality, audit fees and audit market concentration as the three main research strands. The impacts of audit quality and audit costs were the aspects that received major focus from the empirical studies that were assessed. So far only two studies deal with audit market concentration. Given the comparatively easy data generation (e.g. with the accruals models and audit fees), this frequency on the first research strand is not surprising.

Previous studies have mostly shown a positive effect of joint audits on audit quality, where the joint audit pair choice is of central importance. The studies state that both a Big Four joint audit as well as a joint audit with an SME audit firm can improve quality. A tendency towards a positive effect can also be observed with respect to audit fees. In this line of research, the composition of the joint audit team is also essential to affect the cost structure. The two studies on the effect of the audit market concentration show that in EU Member States with a mandatory joint audit regime (currently France, formerly Denmark), the concentration is lower compared to countries with voluntary joint audits. However, it is doubtful whether this condition can be attributed only to the joint audits or if other country-specific effects (e.g. internal and external corporate governance variables) are decisive.

On the basis of the tendencies and limitations found in the literature review, this contribution has indicated some fruitful directions for further research. The studies evaluated here all deal with the research question at the European level. Therefore, an extension of research to examine other markets as well especially that of the United States, would seem an obvious next research object. This is a research desideratum as the international discussion after the global financial crisis is likely to raise novel aspects that will play an important part in future debates. Although our findings about the European corporate governance system can of course not be transferred to that of other countries, they can nevertheless offer some useful pointers in the quest for joint audit effectiveness to current empirical audit research.

\section{References}

1. Alfraih, M. A. (2016). Corporate governance mechanisms and audit delay in a joint audit regulation. Journal of Financial Regulation and Compliance, 24 (online first).

2. André, P., Broye, G., Pong, C., and Schatt, A. (2016). Are Joint Audits Associated with Higher Audit Fees? European Accounting Review, 25, 245-274.

3. Antle, R. (1982). The Auditor as an Economic Agent. Journal of Accounting Research, 20, 503-527.

4. Audousset-Coulier, S. (2015). Audit Fees in a Joint Audit Setting. European Accounting Review, 24, $347-377$.

5. Baldauf, J., and Steckel, R. (2012). Joint Audit and Accuracy of the Auditor's Report. An empirical study. International Journal of Economic Sciences and Applied Research, 5, 7-42. 
6. Ballas, A. A., and Fafaliou, I. (2008). Market shares and concentration in the EU auditing industry. International Advances in Economic Research, 14, 485-497.

7. Bédard, J., Piot, C., and Schatt, A. (2016). An evaluation of the French expertise with joint auditing. Working paper.

8. Bennouri, M., Nekhili, M., and Touron, P. (2015). Does auditors' reputation "discourage" related-party transactions? The French case. Auditing, 34, 1-32.

9. Bisogno, M., and De Luca, R. (2016). Voluntary Joint Audit and Earnings Quality. Evidence from Italian SMEs. International Journal of Business Research and Development, 5, 1-22.

10. Broye, G. (2007). Concentration du marché de l'audit. Un état des lieux. Revue Francaise de Comptabilité, 399, 34-47.

11. Chow, C. (1982). The demand for external auditing. The Accounting Review, 57, 272-291.

12. DeAngelo, L.E. (1981a). Auditor Independence, "Low Balling" and Disclosure Regulation. Journal of Accounting and Economics, 3, 113-127.

13. DeAngelo, L. E. (1981b). Size and Audit quality. Journal of Accounting and Economics, 3, 183-199.

14. Dechow, P. M., and Dichev, I. D. (2002). The quality of accruals and earnings: the role of accrual estimation errors. The Accounting Review, Supplement, 77, 35-59.

15. Dechow, P. M., Ge, W., and Schrand, C. (2010). Understanding earnings quality: A review of the proxoxies, their determinants and their consequences. Journal of Accounting and Economics, 50, 344-401.

16. Dechow, P. M., Richardson, S., and Tuna, I. (2003). Why are earnings kinky? An examination of the earnings management explanation. Review of Accounting Studies, 8, 355-384.

17. Dechow, P. M., Sloan, R. G., and Sweeney, A. P. (1995). Detecting earnings management. The Accounting Review, 70, 193-225.

18. DeFond, M., and Zhang, J. (2014). A review of archival auditing research. Journal of Accounting and Economics, $58,275-326$.

19. Deng, M., Lu, T., Simunic, D., and Ye, M. (2014). Do Joint Audits Improve or Impair Audit Quality? Journal of Accounting Research, 52, 1029-1060.

20. El Assy, M. G. (2015). The Effect of Joint Audit on Audit Quality. Empirical Evidence from Companies Listed on the Egyptian Stock Exchange. International Journal of Accounting and Financial Reporting, 5, 195-207.

21. EC. (2010). European Commission Green Paper, Audit Policy: Lessons from the Crisis. Brussels.

22. EC. (2014). Regulation (EU) No. 537/2014 of the European Parliament and of the Council of 16 April 2014 on specific requirements regarding statutory audit of public-interest entities and repealing Commission Decision 2005/909/EC. Official Journal of the European Union L 158/77.

23. Francis, J.R., Richard, C., and Vanstraelen, A. (2009). Assessing France's joint audit requirement. Are two heads better than one? Auditing, 28(2), 35-63.

24. Gonthier-Besacier, N., and Schatt, A. (2007). Determinants of audit fees for French quoted firms. Managerial Auditing Journal, 22, 139-160.

25. Gros, M., and Worret, D. (2014). The challenge of measuring audit quality: some evidence. International Journal of Critical Accounting, 6, 345-374.

26. Holm, C., and Thinggaard, F. (2014). Leaving a joint audit system: conditional fee reductions. Managerial Auditing Journal, 29, 131-152.

27. Holm, C., and Thinggaard, F. (2016). Paying for Joint or Single Audits? The importance of auditor pairings and differences in technology efficiency. International Journal of Auditing, 20, 1-16.

28. Huang, X. B., and Watson, L. (2015). Corporate social responsibility research in accounting. Journal of Accounting Literature, 34, 1-16.

29. Ittonen, K., and Peni, E. (2012). Auditor's gender and audit fees. The International Journal of Auditing, 16, 1-18.

30. Ittonen, K., and Tronnes, P. C. (2015). Benefits and Costs of Appointing Joint Audit Engagement Partners. Auditing, 34, 23-46.

31. Jensen, M. C., and Meckling, W. H. (1976). Theory of the firm. Journal of Financial Economics, 3, 305-360.

32. Jones, J. J. (1991). Earnings management during import relief investigations. Journal of Accounting Research, 29, 193-228.

33. Knechel, W. R., Krishnan, G. V., Pevzner, M., Shefchik, L. B. and Velury, U. K. (2013). Audit quality: insights from the academic literature. Auditing, 32(1), 385-421.

34. Kothari, S. P., Leone, A. J., and Wasley, C. E. (2005). Performance matched discretionary accrual measures. Journal of Accounting and Economics, 39, 163-197.

35. Larcker, D. F., and Rusticus, T. O. (2010). On the use of instrumental variables in accounting research. Journal of Accounting and Economics, 49, 186-205.

36. Lesage, C., Ratzinger-Sakel, N. V. S., and Kettunen, J. (2016). Consequences of the Abandonment of Mandatory Joint Audit: An Empirical Study of Audit Costs and Audit Quality Effects. European Accounting Review (forthcoming). 
37. Light, R., and Smith, P. (1971). Accumulating Evidence: Procedures for Resolving Contradictions among Different Research Studies. Harvard Educational Review, 41, 429-471.

38. Nekhili, M., Ayadi, W. M. and Chebbi, D. (2014). France`s Joint-Audit Requirement and Audit Fees: The Influence of ownership and governance. Corporate ownership and control, 11, 388-401.

39. Palmrose, Z.-V. (1986). Audit fees and auditor size. Journal of Accounting Research, 24, 97-110.

40. Piot, C. (2007). Auditor concentration in a joint-audit-environment. The French market 1997-2003. Managerial Auditing Journal, 22(2), 161-176.

41. Piot, C. (2008). Concentration et compétitivité du marché de l'audit en France. Une étude longitudinale 1997-2003. Finance Controle Strategie, 11(4), 31-64.

42. Quick, R. (2012). EC Green Paper Proposals and Audit Quality. Accounting in Europe, 9, 17-38.

43. Ratzinger-Sakel, N. V. S., Audousset-Coulier, S., Kettunen, J. and Lesage, C. (2013). Joint Audit: Issues and Challenges for Researchers and Policy-Makers. Accounting in Europe, 10, 175-199.

44. Ross, S. A. (1973). The Economic Theory of Agency. The American Economic Review, 63, 134-139.

45. Schatzberg, J. W. (1990). A Laboratory market investigation of low balling in audit pricing. The Accounting Review, 65, 337-362.

46. Shocker, A., and Sethi, P. (1973). An approach to incorporating societal preferences in developing corporate action strategies. California management review, 15, 97-105.

47. Thinggaard, F., and Kiertzner, L. (2008). Determinants of audit fees. Evidence from a small capital market with a joint-audit requirement. International Journal of Auditing, 12, 141-158.

48. Velte, P., and Azibi, J. (2015). Are Joint Audits a Proper Instrument for Increased Audit Quality? British Journal of Applied Science and Technology, 7, 528-551.

49. Velte, P., and Stiglbauer (2012). Audit Market Concentration and Its influence on audit quality. International Business Research, 5, 146-161.

50. Wood, D. (1991). Corporate social performance revisited. Academy of Management review, 16, $691-718$.

51. Zerni, M., Haapamaki, E., Järvinen, T., and Niemi, L. (2012). Do joint audits improve audit quality? Evidence from voluntary joint audits. European Accounting Review, 12, 731-765.

52. Zerni, M., Kallunki, J. P., and Nillson, H. (2010). The entrenchment problem, corporate governance mechanisms and firm value. Contemporary Accounting Research, 27(4), 1169-1206.

Appendix

Table 2. Empirical joint audit studies

\begin{tabular}{|c|c|c|c|c|}
\hline Year of publication & Authors & $\begin{array}{l}\text { Country } \\
\text { Sample } \\
\text { Time period }\end{array}$ & $\begin{array}{l}\text { Variable(s) of earnings } \\
\text { quality }\end{array}$ & Main significant results \\
\hline \multicolumn{5}{|l|}{ Audit quality } \\
\hline 2016 & Alfraih & $\begin{array}{l}\text { Kuwait } \\
174 \text { companies } \\
2013\end{array}$ & $\begin{array}{l}\text { Lower audit delay } \\
\text { (timeliness) }\end{array}$ & $\stackrel{+}{+}$ \\
\hline 2016 & André et al. & $\begin{array}{l}\text { France, Italy and UK } \\
3,155 \text { firm-year } \\
\text { observations } \\
2007-2011\end{array}$ & Lower abnormal accruals & $+/-$ \\
\hline 2016 & Bisogno and De Luca & $\begin{array}{l}\text { Italy } \\
12,344 \text { observations } \\
2010\end{array}$ & $\begin{array}{l}\text { No occurrence of small } \\
\text { positive earnings }\end{array}$ & + \\
\hline 2016 & Lesage et al. & $\begin{array}{l}\text { Denmark } \\
582 \text { firm-year observations } \\
2002-2010\end{array}$ & Lower abnormal accruals & $+/-$ \\
\hline 2015 & Bennouri et al. & $\begin{array}{l}\text { France } \\
85 \text { firms } \\
2002-2008\end{array}$ & $\begin{array}{l}\text { fewer reports on related- } \\
\text { party transactions }\end{array}$ & (two Big Four joint auditors) \\
\hline 2015 & El Assy & $\begin{array}{l}\text { Egypt } \\
160 \text { firm-year observations } \\
2009-2013\end{array}$ & $\begin{array}{l}\text { higher Earnings } \\
\text { conservatism }\end{array}$ & $\begin{array}{l}\stackrel{+}{\text { (no difference between voluntary und }} \\
\text { mandatory joint audits; no difference in auditor } \\
\text { choice (Big Four versus non-Big Four) }\end{array}$ \\
\hline 2015 & Ittonen and Tronnes & $\begin{array}{l}\text { Finland and Sweden } \\
1,345 \text { firm-year } \\
\text { observations } \\
2005-2009\end{array}$ & Lower abnormal accruals & + \\
\hline 2015 & Velte and Azibi & $\begin{array}{l}\text { Germany and France } \\
\text { 1,535 firm-year } \\
\text { observations } \\
\text { 2008-2012 }\end{array}$ & Lower abnormal accruals & $+/-$ \\
\hline
\end{tabular}


Table 2 (cont.). Empirical joint audit studies

\begin{tabular}{|c|c|c|c|c|}
\hline Year of publication & Authors & $\begin{array}{l}\text { Country } \\
\text { Sample } \\
\text { Time period }\end{array}$ & $\begin{array}{l}\text { Variable(s) of earnings } \\
\text { quality }\end{array}$ & Main significant results \\
\hline 2012 & Zerni et al. & $\begin{array}{l}\text { Sweden } \\
1.257 \text { observations } \\
2001-2007\end{array}$ & $\begin{array}{l}\text { Higher earnings } \\
\text { conservatism, lower } \\
\text { abnormal accruals, better } \\
\text { credit ratings, better risk } \\
\text { forecasts }\end{array}$ & + \\
\hline 2012 & Baldauf and Steckel & $\begin{array}{l}\text { Austria and Germany } \\
35 \text { Statutory auditors } \\
2007\end{array}$ & $\begin{array}{l}\text { Degree of auditor } \\
\text { consensus in the auditor's } \\
\text { report(interview) }\end{array}$ & + \\
\hline 2009 & Francis et al. & $\begin{array}{l}\text { France } \\
467 \text { observations } \\
2003\end{array}$ & $\begin{array}{l}\text { lower abnormal accruals } \\
\text { Determinants of joint audit } \\
\text { pair choice }\end{array}$ & \begin{tabular}{l}
\multicolumn{1}{c}{+} \\
(one or two Big four joint auditors) \\
Companies with less concentrated ownership \\
structures and lower rates of family ownership \\
appoint at least one Big four joint auditor
\end{tabular} \\
\hline \multicolumn{5}{|l|}{ Audit costs } \\
\hline 2016 & André et al. & $\begin{array}{l}\text { France, Italy and UK } \\
3,155 \text { firm-year } \\
\text { observations } \\
2007-2011\end{array}$ & Audit fees & + \\
\hline 2016 & Holm and Thinggaard & $\begin{array}{l}\text { Denmark } \\
261 \text { firm-year observations } \\
2005-2007\end{array}$ & Audit Fees & $\begin{array}{l}+ \text { (Big-Small joint audits, when the small joint } \\
\text { auditor has a share of less than } 25 \% \text { ) }\end{array}$ \\
\hline 2016 & Lesage et al. & $\begin{array}{l}\text { Denmark } \\
582 \\
2002-2010\end{array}$ & Audit fees & + \\
\hline 2015 & Audousset-Coulier & $\begin{array}{l}\text { France } \\
254 \text { firm-year observations } \\
2002-2003\end{array}$ & $\begin{array}{l}\text { Effect of auditor choice on } \\
\text { audit fees }\end{array}$ & $\begin{array}{c}+/ \text { - (two big four auditors, but indication of a big } \\
\text { four premium) }\end{array}$ \\
\hline 2015 & Ittonen and Tronnes & $\begin{array}{l}\text { Finland and Sweden } \\
1,345 \text { firm-year } \\
\text { observations } \\
2005-2009\end{array}$ & Audit Fees & $+/-$ \\
\hline 2014 & Holm and Thinggaard & $\begin{array}{l}\text { Denmark } \\
313(289) \text { firms } \\
2005 \\
\end{array}$ & Audit fees & $\begin{array}{l}\text { (after the switch to single audits by a dominant } \\
\text { auditor) }\end{array}$ \\
\hline 2014 & Nekhili et al. & $\begin{array}{l}\text { France } \\
130 \text { firms } \\
2004-2006\end{array}$ & Audit fees & $\stackrel{+}{+}$ \\
\hline 2012 & Ittonen and Peni & $\begin{array}{l}\text { Denmark, Finland and } \\
\text { Sweden } \\
715 \text { firm-year observations } \\
2005-2006\end{array}$ & Audit fees & $? ? ?$ \\
\hline 2012 & Zerni et al. & $\begin{array}{l}\text { Sweden } \\
1.257 \text { firm-year } \\
\text { observations } \\
2001-2007 \\
\end{array}$ & Audit fees & $\begin{array}{l}\text { Positive link between voluntary joint audits and } \\
\text { audit fees }\end{array}$ \\
\hline 2010 & Zerni et al. & $\begin{array}{l}\text { Sweden } \\
1,171 \text { firm-year } \\
\text { observations } \\
2000-2006 \\
\end{array}$ & Audit fees & $+/-$ \\
\hline 2008 & $\begin{array}{l}\text { Thinggaard and } \\
\text { Kiertzner }\end{array}$ & $\begin{array}{l}\text { Denmark } \\
126 \text { companies } \\
2002\end{array}$ & Audit fees & (de facto joint audits) \\
\hline 2007 & $\begin{array}{l}\text { Gonthier-Besacier and } \\
\text { Schatt }\end{array}$ & $\begin{array}{l}\text { France } \\
127 \text { firms } \\
2002\end{array}$ & Audit fees & $\begin{array}{c}- \\
\text { (two Big Four joint auditors) } \\
+ \\
+ \\
\text { (one non-Big four joint auditor) }\end{array}$ \\
\hline \multicolumn{5}{|c|}{ Audit market concentration } \\
\hline 2008 & Ballas and Fafaliou & $\begin{array}{l}15 \text { European countries } \\
2.862 \\
1998-2001 \text { and } 2002-2004\end{array}$ & $\begin{array}{l}\text { Audit market } \\
\text { concentration }\end{array}$ & $\begin{array}{l}\text { (in France and Denmark after the collapse of } \\
\text { Arthur Andersen) } \\
\text { (in the other countries) }\end{array}$ \\
\hline 2007 & Piot & $\begin{array}{l}\text { France } \\
817 \text { and } 887 \text { firms } \\
1997 \text { and } 2003\end{array}$ & $\begin{array}{l}\text { Audit market } \\
\text { concentration }\end{array}$ & $\begin{array}{l}\text { (in France in comparison to the rest of Europe) } \\
\text { (over time in France) }\end{array}$ \\
\hline
\end{tabular}

